\title{
Reflections on The Fourth Wave of Democratization: The Indonesian Case
}

\author{
Bahtiar Effendy \\ UIN Jakarta
}

\begin{abstract}
This essay is about the need to re-examine the substantive goals of democracy. From the first to the fourth wave of democracy, many - if not all- countries have been forced to witness the practice of democracy in its procedural biases. In many of the emerging democratic countries such a practice has not been able to guarantee the development of a state in which public goods are accessible to all and prosperity becomes a common objective. For this, the conception of a democratic government must include the substantive goals of why a state is formed in the first place.
\end{abstract}

Keywords - Democracy, fourth wave, Indonesia's democracy

\section{THE FOURTH WAVE OF DEMOCRATIZATION}

Many theorists believe that democracy can only be understood and practiced in the context of procedure. Not all of them, of course, but many do. Juan Linz is one of the most well-known scholars who see procedure as the most practical way to understand and practice democracy. For him, a political regime can be called democratic when "it allows the formulation of political preferences through the use of basic freedoms of associations, information and communication, for the purpose of free competition between leaders to validate at regular intervals by non-violent means they claim to rule ..., without excluding any effective political office from that competition or prohibiting any members of the political community from expressing their preference.[1]

In short, as suggested by Richard Gunther, another proponent of procedural democracy theory, "a country is called democratic in so far as it organizes free and fair elections at a regular interval, in a non-violent way, without excluding anybody to take part in it [2].

Under such a strong paradigm, voting and elections become the heart and soul of (procedural) democracy. Indeed, as Samuel Huntington, a notable conservative theorist of political development, suggests in his The Third Wave: Democratization in the Late Twentieth Century, "(1) 50 percent of the adult males are eligible to vote; and (2) a responsible executive who either must maintain majority support in an elected parliament or is chosen in periodic popular elections.[3]

Based on these two criteria, according to Huntington, the US was perceived as the pioneer of democracy in 1828. In the decades to come, several European countries such as Switzerland, France, Great Britain joined the bandwagon in the first wave of democracy.

This first wave ended in the1930s, only to resurface for the second time in the 1940s and early 1950s. The end of the Second World War and the dismantling of colonial rule that led to the emergence of the newly independent states paved the way for the upsurge of democracy. In this period, Indonesia--albeit briefly-- rode the second wave of democracy together with many other countries such as West Germany, Italy, Austria, Japan, Uruguay, Costa Rica, India, Sri Lanka, and the Philippines--as listed in The Third Wave.

This second wave ceased to roll in the late 1950s as many of the new states, especially those in the underdeveloped world category, faced tremendous challenges of governing where their capacity to deliver what they had promised was very much under serious scrutiny. Unable to meet these challenges, what followed in the ensuing years were democratic breakdowns in the 1960s and 1970s. The imposition of martial law by either military or civilian governments in Pakistan in 1958 and in the Philippines in 1972, the military coup in Korea in 1961, and the suspension of democratic practices in Indonesia in 1957/1959 and in India in 1973 marked the emergence of non-competitive or authoritarian regimes most notably in Asia and Latin America.

The reasons for these breakdowns are many. But generally they revolved around the fact that many of the new states were unable to balance stability and order with the growing public participation and the management of diverse interests.

In spite of this, the democratic wave did not cease. It kept rolling and re-emerging when circumstances warranted. A combination of economic and political crises plus the declining legitimacy of non-competitive regimes gave way to the third wave of democracy in the mid-1970s. As can be read in the four volumes of Transitions from Authoritarian Rule, edited by Guillermo O'Donnell, Philippe C. Schmitter, and Laurence Whitehead, it started with several Southern European countries like Portugal, Spain, and Italy.[4] Just around that decade, these countries experienced tremendous 
crises that led to the collapse of their authoritarian or dictatorial regimes and the emergence of democratic governments. Similar developments also took place in many Latin and Central American countries including --most notably--Argentina, Brazil, Chile, Mexico, Nicaragua, and Haiti.

The cold war which was won by the US in the late 1980s not only unraveled the institutional structure of the Soviet Union, where its member or satellite states liberated themselves from their occupying or metropole state, but also freed them to adopt a democratic system of government. The natural effect of the defeat of the Soviet Union was the collapse of Eastern European communist governments which eventually led to democratic transitions in Poland, Romania, East Germany, Czechoslovakia, and many others. With that, it is safe to say that these countries represented the last surge of democratization in the twentieth century's third wave.

For more than twenty years, these three regions -Southern Europe, Latin America, and Eastern Europe-dominated theoretical discourse on the collapse of authoritarian regimes as well as the transition to democracy and its consolidation. In fact, some, like Spain, Brazil and Argentina, became text-book examples of democratic transitions par excellence.

Reading Huntington's--and many others'--accounts, the third wave was nothing but a success story of democratic transformation. Even though many of them experienced difficulties in their efforts to consolidate their democracies, none of them suffered breakdowns the way many countries did in the first and second waves of democratization. In other words, actually there was no lag, no fallback, with respect to democracies that emerged at the end of the twentieth century and democracies that emerged at the beginning of the twenty first century.

But perhaps because of the distinctive features of the event, in my view Indonesia's transition to democracy in 1998 can be regarded as part of the fourth wave of democratization. Huntington did not substantively identify factors that he used to categorize the waves of democratization: the first, the second, and the third. But he did mention, however, as implied above, the year the event of transition or the emergence of democracy took place. Because of that, I take the liberty to offer my own reasons why Indonesia's democracy falls in the category of the fourth wave.

My argument in suggesting that Indonesia can be considered as part of the fourth wave has to do basically with its dramatic circumstance. This started with the collapse of Indonesia's authoritarian regime, which was immediately followed by the transition to democracy, occurring almost at the very beginning of the twenty-first century.

Second, though in a way the process solidified a wellknown sociological-political maxim --that authoritarianism breeds crises-- it was made possible by monetary/financial crises that hit Asia hard (especially Thailand, Malaysia, and Indonesia) in 1997. In less than a year, this crisis caused the rupiah to plummet from Rp. 2500 to Rp. 17000 against US \$1. Because of that, President Soeharto's mandate to rule for a seventh term, renewed on March 11, 1998, only survived for three months. On May 21 of the same year, he was forced to resign from the office he had held for thirty two years.

My third reason is the immediacy of the transition following President Soeharto's departure from office.
Realizing the urgency of the situation, President B. J. Habibie sped up the holding of a general election to 1999 from its originally scheduled date of 2002.[5]

Fourth, as already mentioned, Indonesia's transition to democracy occurred at almost the beginning of the twentyfirst century. Perhaps this factor alone was enough to put Indonesia's experience in the fourth wave, but certainly there is no drama in it.

A few years ago the Arab Spring offered a new hope that democratic transitions may actually penetrate the heartland of the Muslim world [6]. Soon we realized, however, that this hope was disproportionate. Tunisia, Egypt, and certainly Iraq and Syria, which experienced regime changes and still face tremendous challenges of survival as sovereign states, are certainly not candidates for democracy -at least in these early decades of the twenty first century [7]

As predicted, for nearly two decades, Indonesia's democracy has tended to demonstrate its procedural bias -though not without its own problems [8]. Unfortunately, the transition did not lead to the development of political elites in almost every branch of government who meet our basic expectations for good governance. As a result, our democratic elites and public office holders have not yet become committed to the substantive notion of higher quality democracy. While the quality of our elections certainly meets the basic standard for a democracy, the economy, education, health and welfare, for instance, have not seen comparable achievements. Because of that, the most conspicuous phenomenon in Indonesian politics is still power politics, perceived as the key means to accumulate wealth and resources that are increasingly scarce.

Should we aspire to a sustainable democracy, a democracy that does not stop short at procedures, then it is high time to connect democracy with its substance. A regime or government may be called undemocratic not only because of its failure to hold a free and fair election but also because of its inability to demonstrate its compassion to the less fortunate as well as to create economic growth and prosperity for all. $* * *$ 


\section{References:}

[1] LINZ, JUAN J., TOTALITARIAN AND AUTHORITARIAN REGIMES, UK: LYNNE RIENNER PUBLISHER, INC, 2000

[2] Higley, John, Richard Gunther (Ed.), Elites and Democratic Consolidation in Latin America and Southern Europe, New York: Cambridge University Press, 1992

[3] Huntington, SAMuel P., THE THiRd WAVE: DEMOCRATIZATION IN THE LATE TWENTIETH CENTURY, NORMAN AND LONDON: THE UNIVERSITY OF OKLAHOMA PRESS, 1991

[4] O'Donnell, Guillermo, Philippe C. Schmitter, and Laurence Whitehead (Ed.), Transitions from Authoritarian Rule, Baltimore: The Johns Hopkins Press University Press, 1991

[5] Effendy, Bahtiar, and Mutiara Pertiwi, “Indonesia's Democratic Venture: Problems, Prospect, and Remaining Challenges,” in Sergio Bitar \& Abraham F. Lowenthal (eds.), Putting Principles into Practices, Democratic Transitions: Conversation With World Leaders, Baltimore, MD: Johns Hopkins University Press, 2015

[6] Haas, Mark L., and David W. Lesch (Ed.), The Arab Spring, The Hope and Reality of the Uprisings, Boulder: Westview Press, 2017.

[7] Esposito, John L., Tamara Sonn, and John O. Voll, Islam and Democracy after the Arab Spring, New York: Oxford University Press, 2016.

[8] Aspinall, Edward, Marcus Mietzner (Ed.), Problems of Democratisation in Indonesia: Elections, Institutions and Society, Singapore: ISEAS, 2010. 